\title{
STRATEGI PENJUALAN BATAKO UKM ARETA AGUNG DENGAN MARKETING MIX DAN PRODUKTIVITAS PARSIAL
}

\author{
Yoseph Tulus Adi W, Dominikus Budiarto ${ }^{2}$ \\ 1,2Program Studi Teknik Industri, Univeristas Katolik Musi Charitas Palembang, Indonesia. \\ Email: 1yosephtulus@gmail.com, ${ }^{2}$ dombuw07@gmail.com
}

\begin{abstract}
Small and Medium Enterprises (SME) of Areta Agung is a brick-and-mortar SME in the city of Palembang. The purpose is to increase the productivity of brick sales. The results based on sales data Market Share as much as 24\%. Before improving the strategy formulate external and internal factors. Externally using benchmarking data, namely the comparison of similar SME factors and internal results from brainstorming, namely data obtained from the results of SME of Areta Agung. In this study SWOT analysis is used to find out the strengths, weaknesses, opportunities, threats faced by SME. After that, the SWOT matrix generates an improvement strategy, which is then improved using the Marketing Mix (4P). Its implementation includes products, namely receiving services outside of operations. Price is the addition of price variations for shipping outside the city. Promotion, namely making online sales advertisements, sales promotions, publicity, personal selling. The place is to add a building depot subscription. The results obtained by Partial Productivity before preparation were 0.565 .
\end{abstract}

Keywords: Market Share, Internal and External Factor, SWOT Analysis, Marketing Mix, Parsial Productivity

\section{PENDAHULUAN}

Bata beton (batako) adalah salah satu bahan bangunan yang berupa batubatuan yang pengerasannya tidak di bakar dengan bahan campuran yang berupa pasir, semen, air dan dalam pembuatan tambahan lainnya dapat ditambahkan dengan bahan lainnya (aditive) [1]. Batako pada saat ini semakin populer digunakan sebagai pengganti batu bata merah. Hal ini disebabkan karena batako dinilai lebih cepat dalam pembuatan maupun pengerjaannya untuk pasang dinding. Maka secara tidak langsung kebutuhan batako akan meningkat sebagai pengganti penggunaan batu bata dan seiring dengan pembangunan perumahan.

UKM Areta Agung merupakan salah satu industri batako yang terletak di kota Palembang. Dengan jumlah 3 mesin cetak batako serta karyawan 6 orang mampu mencetak dalam sehari 1500 unit Batako. Untuk 1 bulan kapasitas produksi yang dimiliki oleh UKM Areta Agung sebanyak 37.500 unit batako dalam 1 bulan produksi. Masalah yang dialami yaitu penjualan yang rendah diakibatkan oleh kurangnya pengetahuan menyebabkan jangkauan area Market Share rendah. Dalam memperbaiki kekurangan yang di miliki oleh UKM Areta 
Agung dan tidak adanya sarana promosi sehingga produktivitas penjualan masih rendah. Setiap bulannya, UKM Areta Agung rata-rata hanya mampu menjual Batako sebanyak 15.000 unit Batako. dengan pendapatan kotor rata-rata tiap bulannya Rp 30.000.000. Dengan permasalahan yang terjadi mengakibatkan penjualan tidak dapat menutupi biaya operasional dalam pembuatan batako.

Pada penelitian ini menggunakan metode Marketing Mix adalah perangkat alat penjualan yang digunakan perusahaan untuk mengejar tujuan perusahaannya [2]. Kompenen tersebut terdiri dari 4P yaitu Product (produk), Price (harga), Promotion (promosi), Place (tempat). Setelah melakukan perbaikan, penelitian ini menggunakan perhitungan Produktivitas Parsial yang bertujuan untuk mengukur tingkat produktivitas penjualan produk batako sebelum dan sesudah perbaikan. Produktivitas Parsial yaitu salah satu alat ukur bagi perusahaan dalaam menilai prestasi kerja yang dicapai dengan pengukuran salah satu faktor atau masukan (input) yang digunakan untuk menghasilkan Keluaran (output). Faktor atau masukan (input) yaitu tenaga kerja, bahan baku (material), energi, modal [3]. Selain itu, menggunakan analisis SWOT sebelum melakukan perbaikan penjualan. Analisis SWOT yaitu analisis untuk mendapatkan strategi yang berguna atau efektif yang diterapkan sesuai pasar dan keadaan publik saat itu, peluang (opportunity) dan ancaman (threat) di pakai untuk mengetahui lingkungan luar atau eksternal kemudian kekuatan (strength) dan kelemahan (weakness) yang didapatkan melalui analisis dalam perusahaan atau internal [4]. Analisis SWOT digunakan untuk dasar perbaikan dari hasil faktor ekternal dan internal dengan bantuan data benchmarking dan brainstorming.

UKM Areta Agung dalam melakukan perbaikan peningkatan penjualan batako harus menyesuaikan jumlah pengeluaran sehingga tidak terjadi kerugian terhadap UKM. Penelitian ini bertujuan untuk Mengatasi permasalahan penjualan UKM Areta Agung dan meningkatkan produktivitas penjualan UKM Areta Agung. Berdasarkan permasalahan diatas dapat dirumuskan yaitu bagaimana merumuskan Strategi penjualan Pada UKM Areta Agung guna meningkatkan produktivitas?

\section{METODOLOGI PENELITIAN}

Keseimbangan penjualan batako perlu diberikan solusi dengan pendekatan Marketing Mix. Pendekatan diharapkan meningkatkan penjualan UKM Areta Agung. Pendekatan Marketing Mix akan dikaitkan dengan menggunakan Analisis SWOT yang akan berhubungan dalam menentukan strategi perbaikan penjualan batako. Oleh sebab itu, selain memberikan solusi dilakukan juga perhitungan produktivitas guna mengetahui produktivitas tenaga kerja, bahan baku (material), energi, modal.

Metologi dalam penelitian ini adalah peningkatan penjualan dengan metode Markering Mix dan produktivitas parsial pada UKM Areta Agung. Flowchart diagram alir penelitian secara detail dapat di lihat pada gambar 2.1. 


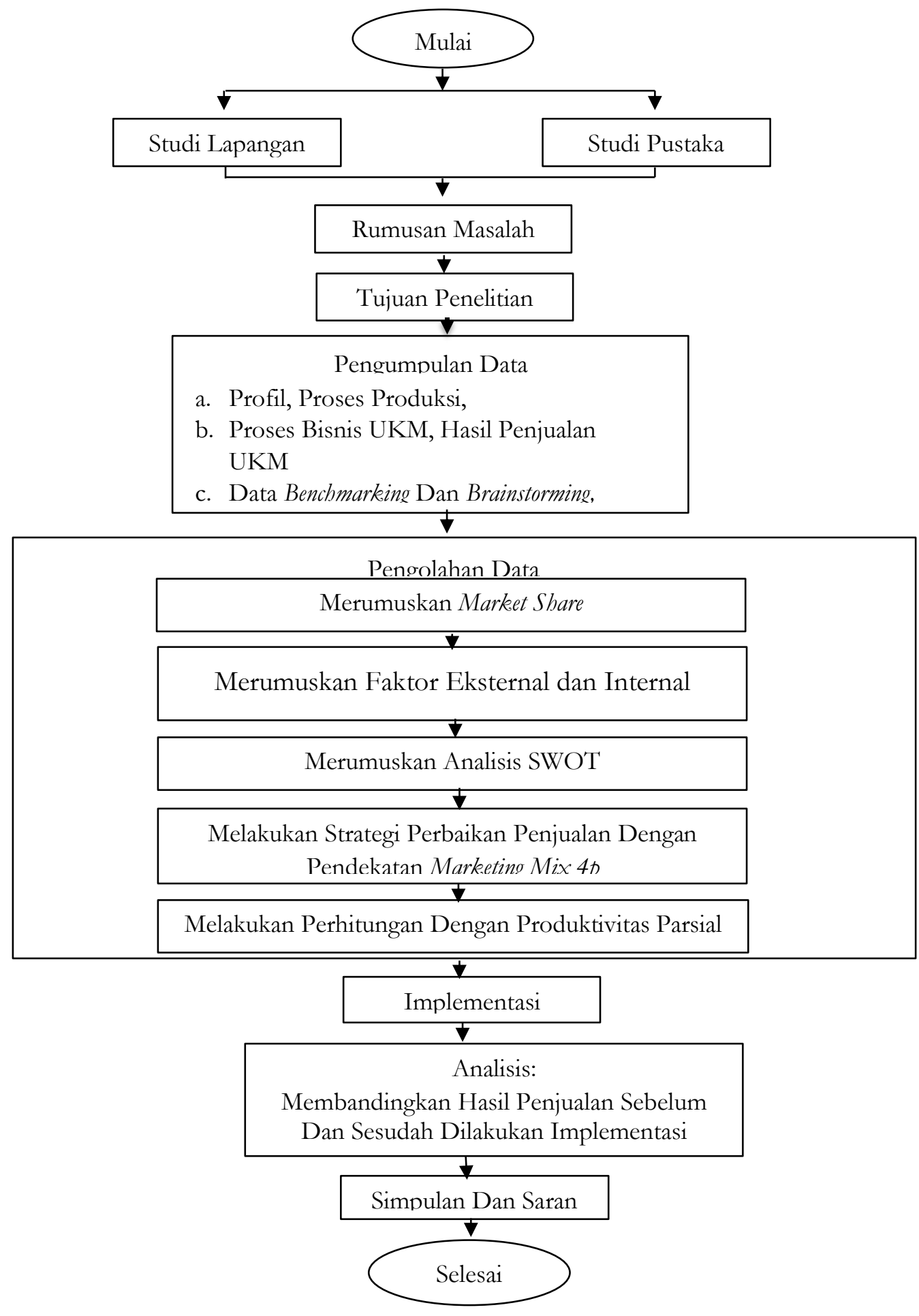


(Civil Engineeering, Elektrical Engineeering and Industrial Engineeering)

Vol 18. , No : 2 Oktober 2021, p-ISSN:1907-5243, e-ISSN: 2655-8416

\section{Gambar 2.1. Flowchart Alur Metodologi Penelitian \\ 3. HASIL DAN PEMBAHASAN}

Berdasarkan hasil analisa jumlah Market Share UKM Areta Agung yang dikuasai ditunjukan pada diagram pie. Berikut diagram pie dinyatakan pada gambar 3.2

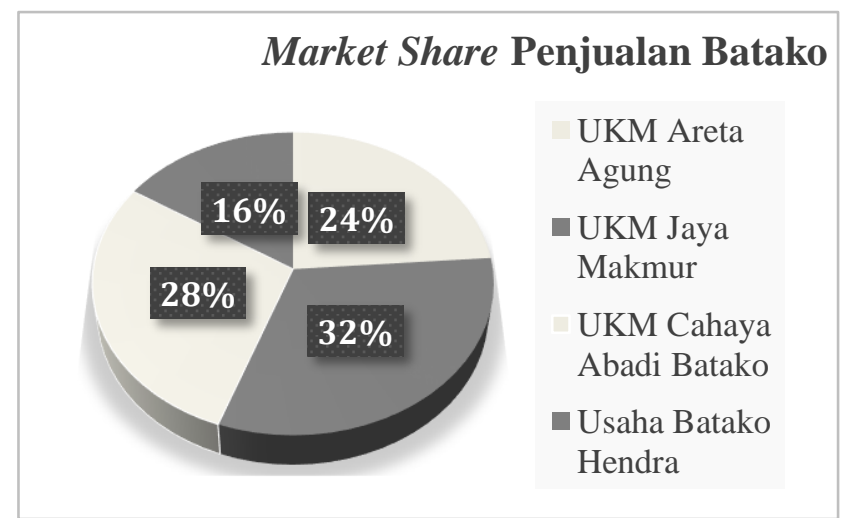

Gambar 3.2 Diagram Pie Market Share Penjualan Batako

Berdasarkan diagram pie diatas UKM Areta Agung memiliki Market Share penjualan batako sebesar $24 \%$ dari 4 produsen batako yang ada. Jumlah tersebut masih dikatakan rendah sehingga perlu adanya perbaikan penjualan batako.

Analisa selanjutnya, menentukan analisis SWOT. Dalam melakukan analisis SWOT, ada dua faktor yang diperhatikan yaitu faktor internal dan faktor eksternal UKM. Faktor internal ini mempengaruhi terbentuknya strengths and weakness ( $\mathrm{S}$ and W). Dimana faktor ini menyangkut dengan kondisi yang terjadi dalam UKM, yang mana ini turut mempengaruhi terbentuknya pembuatan keputusan UKM. Faktor internal dari UKM Areta Agung diidentifikasi berdasarkan hasil brainstorming. Brainstorming dilakukan dengan menggunakan teknik wawancara dengan pemilik. Berdasarkan hasil wawancara, diperoleh bahwa aspek kekuatan yang dimiliki diantaranya pengantaran secara gratis, harga terjangkau, lokasi strategis Sedangkan kelemahan yang dimiliki diantaranya keterbatasan pelayanan pemesanan hanya saat jam operasional, belum adanya variasi harga sehingga tidak dapat dijualkan luar Palembang, kegiatan promosi kurang, proses pelayanan masih menggunakan via telepon atau datang pabrik secara langsung. Selain faktor internal, terdapat juga faktor eksternal. Dimana faktor ini menyangkut dengan kondisi -kondisi yang terjadi di luar UKM yang mempengaruhi dalam pembuatan keputusan UKM. Dalam menentukan faktor eksternal didapatkan dari hasil benchmarking. Berdasarkan hasil benchmarking, peluang yang dimiliki diantaranya permintaan batako yang terus meningkat dan kebutuhan masyarakat dalam membangun murah dan cepat. Setelah mengetahui faktor ekternal dan internal selanjutnya membuat matriks SWOT. Matriks SWOT 
merupakan matching tool yang penting untuk membantu mengembangkan empat tipe strategi, yaitu strategi S-O (Strength-Opportunity), strategi W-O (Weakness-Opportunity), strategi S-T (Strength-Threat), dan strategi W-T (Weakness-Threat) [5]. Masing - masing strategi yang ada, diperoleh berdasarkan hasil pertimbangan faktor eksternal dan faktor eksternal yang ada dilapangan. Strategi SO (Strength-Opportunity), strategi menggunakan kekuatan internal perusahaan untuk meraih peluangpeluang yang ada di luar perusahaan. Strategi WO (Weakness-Opportunity), strategi ini bertujuan untuk memperkecil kelemahan-kelemahan internal perusahan dengan memanfaatkan peluang-peluang perusahaan. Strategi S-T adalah strategi yang digunakan untuk menghindari atau mengurangi dampak dari ancaman-ancaman eksternal dengan menggunakan kekuatan yang di miliki. Strategi W-T adalah strategi untuk bertahan dengan cara mengurangi kelemahan internal serta menghindari ancaman yang ada. Formulasi strategi dengan menggunakan matriks SWOT dapat dilihat pada tabel 3.1 di bawah ini

Tabel 3. 1 Matriks SWOT

\section{Kekuatan (S)}

1. Pengantaran batako secara gratis,

2. Harga produk yang terjangkau,

3. Lokasi tempat yang startegis,

\section{Peluang (O)}

1. Jumlah pemesanan batako,

2. Keinginan masyarakat dalam membangun cepat dan murah.

\section{Strategi S-O}

1. Penetrasi pasar $\left(\mathrm{S}_{1,}, \mathrm{~S}_{2}, \mathrm{O}_{1}, \mathrm{O}_{2}\right)$

\section{Kelemahan (W)}

1. Layanan operasional hanya dapat dilakukan pada saat jam operasional UKM Areta Agung,

2. Harga jual batako tidak untuk pengiriman luar kota Palembang,

3. Kegiatan promosi masih terbatas,

4. Area Penjualan hanya di kota Palembang,

5. Proses pelayanan secara konvensional yaitu datang langsung dan via telepon.

\section{Strategi W-O}

1) Menambah jam layanan pesanan $\left(\mathrm{W}_{1}, \mathrm{~W}_{5}, \mathrm{O}_{1}\right)$

2) Menambah variasi harga

$\left(\mathrm{W}_{1}, \mathrm{~W}_{4}, \mathrm{O}_{1}, \mathrm{O}_{2}\right)$ 


\section{Ancaman (T)}

1.Persaingan yang tinggi dihadapi oleh UKM Areta Agung,

2.UKM pesaing sejenis dalam penjualan batako tidak hanya mencakup kota Palembang melainkan sudah mencakup Sumatra Selatan,

3.Harga jual dipasaran berbeda-beda menjadikan konsumen memiliki ketertarikan memilih produsen

\author{
3) Meningkatkan \\ media promosi \\ produk \\ $\left(\mathrm{W}_{3}, \mathrm{~W}_{4}, \mathrm{~W}_{5}, \mathrm{O}_{1}\right)$
}

Strategi S-T

1.Perbaikan penjualan

Produk menggunakan Marketing Mix $\left(\mathrm{S}_{1}, \mathrm{~S}_{2}\right.$, $\left.\mathrm{T}_{1}, \mathrm{~T}_{2}, \mathrm{~T}_{3}, \mathrm{~T}_{4}\right)$

\section{Strategi W-T}

1. Menambah saluran penjualan $\left(\mathrm{W}_{3}, \mathrm{~W}_{5}, \mathrm{~T}_{1}, \mathrm{~T}_{2}\right)$

4. Kenaikan bahan bakar

Tabel diatas merupakan formulasi strategi dengan menggunakan analisis matriks SWOT. Alternatif strategi yang diperoleh dari matriks SWOT diantaranya strategi S-O yaitu Penetrasi pasar. Strategi W-O yaitu menambah jam layanan pesanan, menambah variasi harga, meningkatkan media promosi produk. Startegi S-T yaitu Perbaikan penjualan Produk menggunakan Marketing Mix. Startegi W-T yaitu Menambah saluran penjualan. Setelah didapatkan matriks SWOT strategi, selanjutnya implementasi dengan Marketing Mix yaitu product (produk), price (harga), promotion (promosi), place (tempat). Berikut ini implementasi Strategi penjualan Batako UKM Areta Agung

1) Strategi Product (Produk)

Pada penelitian ini, untuk menjaga layanan produk tetap baik melakukan strategi perbaikan yaitu memberikan layanan diluar jam operasional melalui sosial media. Layanan operasional yang pada awalnya UKM Areta Agung hanya melayani pemesanan batako saat jam operasional yaitu pukul $08.00-$ 16.00 menjadi bisa diluar jam operasional dengan penggunaan sosial media.

2) Strategi Price (Harga)

Pada penelitian ini perbaikan yang dilakukan oleh UKM Areta Agung yaitu bagi pengiriman untuk di luar kota Palembang. UKM Areta Agung memberikan harga khusus sebesar Rp. 2.200 per batako serta memiliki 
syarat minimal pemesanan sebanyak 1.200 unit batako serta harga tersebut memiliki batas jarak sejauh $30 \mathrm{~km}$.

3) Strategi Promotion (Promosi)

Pada penelitian ini perbaikan yang dilakukan yaitu pertama membuat iklan penjualan online di facebook. Dengan mengiklankan produk sebagai media promosi efektif dikarenakan kegiatan promosi dengan menggunakan sosial media gratis (tidak berbayar) dan juga saat ini banyak orang yang menggunakan sosial media. Kedua, promosi penjualan. Dengan memberikan diskon kepada konsumen yang berlangganan memesan batako dan menjelaskan contoh produk batako kepada calon pembeli sehingga dapat promosikan penjualan pada konsumen. Ketiga, publisitas. Dengan membuat komentar tentang produk batako UKM Areta Agung yang disampaikan oleh pelanggan kepada media sosial sehingga masyarakat mengetahui produk batako UKM Areta Agung. Keempat, penjualan pribadi. Komunikasi langsung (tatap muka) antara penjual dan calon pelanggan untuk memperkenalkan suatu produk kepada calon pelanggan dan membentuk pemahaman pelanggan terhadap produk serta menerapkan prinsip 5S (senyum,sapa,salam,santun,sopan) sehingga mereka kemudian akan mencoba dan membelinya.

4) Strategi Place (Tempat)

Pada penelitian ini, strategi tempat (place) yang dilakukan adalah penambahan jumlah depot bangunan yang menjadi langganan pada UKM Areta Agung. Penambahan jumlah depot bangunan dengan tujuan utama untuk memperluas jangkauan penjualan dan memudahkan konsumen untuk mendapatkan produk batako dari UKM Areta Agung.

Analisis selanjutnya adalah melakukan perhitungan produktivitas parsial. Ukuran produktivitas parsial bisa di lihat dengan dua cara yaitu produktivitas operasional dan produktivitas finansial [4]. Produktivitas opersional adalah rasio unit output terhadap unit input sedangkan produktivitas finansial juga merupakan rasio output terhadap input, tetapi angka pembilang atau penyebutnya dalam satuan mata uang (rupiah). Sebelum menghitung produktivitas, terlebih dahulu harus diketahui jumlah permintaan sebelum dan sesudah implementasi perbaikan. Tabel perbandingan jumlah permintaan sebelum dan sesudah dilakukan implementasi perbaikan dapat dilihat pada tabel 3. 2 di bawah ini.

Tabel 3. 2 Jumlah penjualan sebelum dan sesudah implementasi perbaikan

\begin{tabular}{|c|c|c|c|c|c|}
\hline \multicolumn{3}{|c|}{ Sebelum perbaikan } & \multicolumn{3}{|c|}{ Sesudah Perbaikan } \\
\hline 1 & Penjualan & & 1 & Penjualan & \\
\hline & Umum & 6480 & & Umum & 9310 \\
\hline 2 & Penjualan & & 2 & Penjualan & \\
\hline & Langganan & 8540 & & Langganan & 6635 \\
\hline
\end{tabular}


(Civil Engineeering, Elektrical Engineeering and Industrial Engineeering)

Vol 18. , No : 2 Oktober 2021, p-ISSN:1907-5243, e-ISSN: 2655-8416

15020

3 Penjualan

Luar Kota

2250

Palembang

Unit/bulan

Total

18195

Dilihat dari sesudah implemetasi perbaikan, diketahui bahwa jumlah permintaan batako meningkat menjadi 18195 dan mengalami peningkatan permintaan batako sebanyak 3175 jika dibandingkan dengan sebelum implementasi perbaikan. Untuk melakukan perhitungan pengukuran produktivitas parsial. Membuat tabel output dan input biaya produksi per bulan UKM Areta Agung sebelum implementasi perbaikan (bulan April 2021) dapat di lihat pada tabel 3.3 di bawah ini.

Tabe1 3. 3 Output dan input biaya produksi per bulan UKM Areta Agung sebelum implementasi perbaikan

\begin{tabular}{|c|c|c|c|c|}
\hline No & Rincian & $\begin{array}{c}\text { Jumlah } \\
\text { Pemakaian } \\
\text { Per Bulan }\end{array}$ & $\begin{array}{c}\text { Harga Satuan } \\
(\mathbf{R p})\end{array}$ & $\begin{array}{c}\text { Total Harga } \\
\text { (Rp) }\end{array}$ \\
\hline \multicolumn{5}{|c|}{ Input } \\
\hline & Biaya Sewa & & & \\
\hline 1 & Tanah & 1 Bulan & 416.666 & 416.666 \\
\hline 2 & Air & 1 Bulan & 120.000 & 120.000 \\
\hline 3 & $\begin{array}{l}\text { Solar Produksi } \\
\text { Solar }\end{array}$ & 30 Liter & 5.150 & 154.500 \\
\hline 4 & Transportasi & 40 Liter & $\mathrm{Rp} \quad 5.150$ & $\mathrm{Rp} \quad 206.000$ \\
\hline 5 & Biaya Pekerja & 9 Orang & $\mathrm{Rp} 1.040 .000$ & $\begin{array}{ll}\mathrm{Rp} & 9.360 .000\end{array}$ \\
\hline 6 & Pasir & 104 Kubik & $\mathrm{Rp} \quad 75.000$ & Rp 7.800 .000 \\
\hline 7 & Semen & 208 sak & Rp $\quad 62.000$ & Rp 12.896 .000 \\
\hline 8 & Oli Mesin & 1 botol & $\mathrm{Rp} \quad 300.000$ & $\mathrm{Rp} \quad 300.000$ \\
\hline & & Total Input & & Rp 31.253.166 \\
\hline \multicolumn{5}{|c|}{ Output } \\
\hline \multicolumn{5}{|c|}{6.480} \\
\hline 1 & $\begin{array}{l}\text { Penjualan } \\
\text { Umum }\end{array}$ & $\begin{array}{c}\text { Unit/bulan } \\
\text { Batako } \\
8.540\end{array}$ & 2.000 & Rp 12.960 .000 \\
\hline 2 & $\begin{array}{l}\text { Penjualan } \\
\text { Langganan }\end{array}$ & $\begin{array}{c}\text { Unit/bulan } \\
\text { Batako } \\
\text { Total Output }\end{array}$ & 1.800 & $\begin{array}{l}\text { Rp } 15.372 .000 \\
\text { Rp 28.332.000 }\end{array}$ \\
\hline
\end{tabular}

Berdasarkan tabel 3.3 jumlah input yang dikeluarkan yaitu sebesar Rp 31.253.166, sedangkan jumlah output yang dihasilkan yaitu sebesar Rp 28.332.000. Pengukuran aktivitas produktifitas dinyatakan sebagai berikut [6] 
(Civil Engineeering, Elektrical Engineeering and Industrial Engineeering)

Vol 18. , No : 2 Oktober 2021, p-ISSN:1907-5243, e-ISSN: 2655-8416

Labour Productivity

$$
\begin{aligned}
& =\frac{\text { Total Output }}{\text { Labour Input }(\text { Biaya Pekerja })} \\
& =3.026923077 \approx 3.027
\end{aligned}
$$

Capital Productivity

$$
\begin{aligned}
& =\frac{\text { Total Output }}{\text { Capital Input }(\text { Total Input })} \\
& =0.9065336077 \approx 0.906
\end{aligned}
$$

Material Productivity

Total Output

$$
\begin{aligned}
& =\overline{\text { Material Input }(\text { Air }+ \text { Pasir }+ \text { Semen })} \\
& =1.361068409 \approx 1.361
\end{aligned}
$$

Energy Productivity

Total Output

Energy Input(Solar Produksi+Solar Transportasi+Oli Mesin $=42.89477668 \approx 42.895$

Total Productivity

$$
\begin{aligned}
& =\frac{\text { Total Output }}{\text { Total Input }} \\
& =\frac{\text { Total Output }}{(\text { Human }+ \text { Material }+ \text { Capital }+ \text { Energy })} \\
& =0.4563081853 \approx 0.456
\end{aligned}
$$

\begin{tabular}{|c|c|c|c|c|c|c|}
\hline \multirow[t]{2}{*}{ No } & \multirow[t]{2}{*}{ Rincian } & $\begin{array}{c}\text { Jumlah } \\
\text { Pemakaian } \\
\text { Per Bulan } \\
\end{array}$ & \multicolumn{2}{|c|}{$\begin{array}{c}\text { Harga Satuan } \\
\text { (Rp) }\end{array}$} & \multicolumn{2}{|c|}{$\begin{array}{c}\text { Total Harga } \\
\text { (Rp) }\end{array}$} \\
\hline & & \multicolumn{5}{|c|}{ Input } \\
\hline & Biaya Sewa & & & & & \\
\hline 1 & Tanah & 1 Bulan & $\mathrm{Rp}$ & 416.666 & $\mathrm{Rp}$ & 416.666 \\
\hline 2 & Air & 1 Bulan & $\mathrm{Rp}$ & 120.000 & $\mathrm{Rp}$ & 120.000 \\
\hline 3 & $\begin{array}{l}\text { Biaya Solar } \\
\text { Produksi } \\
\text { Biaya Solar }\end{array}$ & 30 Liter & $\mathrm{Rp}$ & 5.150 & $\mathrm{Rp}$ & 154.500 \\
\hline 4 & Transportasi & 67 Liter & $\mathrm{Rp}$ & 5.150 & $\mathrm{Rp}$ & 345.050 \\
\hline 5 & Biaya Pekerja & 9 Orang & $\mathrm{Rp}$ & 1.040 .000 & $\mathrm{Rp}$ & 9.360 .000 \\
\hline 6 & Pasir & 104 Kubik & $\mathrm{Rp}$ & 75.000 & $\mathrm{Rp}$ & 7.800 .000 \\
\hline 7 & Semen & $208 \mathrm{Sak}$ & $\mathrm{Rp}$ & 62.000 & $\mathrm{Rp}$ & 12.896 .000 \\
\hline
\end{tabular}

Dari perhitungan di atas, produktivitas sebelum implementasi perbaikan dengan total produktivitas sebesar 0,456. Untuk melakukan perhitungan pengukuran produktivitas parsial. Membuat tabel output dan input biaya produksi per bulan UKM Areta Agung sesudah implementasi perbaikan (bulan Mei 2021) dapat di lihat pada tabel 3.4.

Tabe1 3. 4 Output dan input biaya produksi per bulan UKM Areta Agung sesudah implementasi perbaikan 
(Civil Engineeering, Elektrical Engineeering and Industrial Engineeering) Vol 18. , No : 2 Oktober 2021, p-ISSN:1907-5243, e-ISSN: 2655-8416

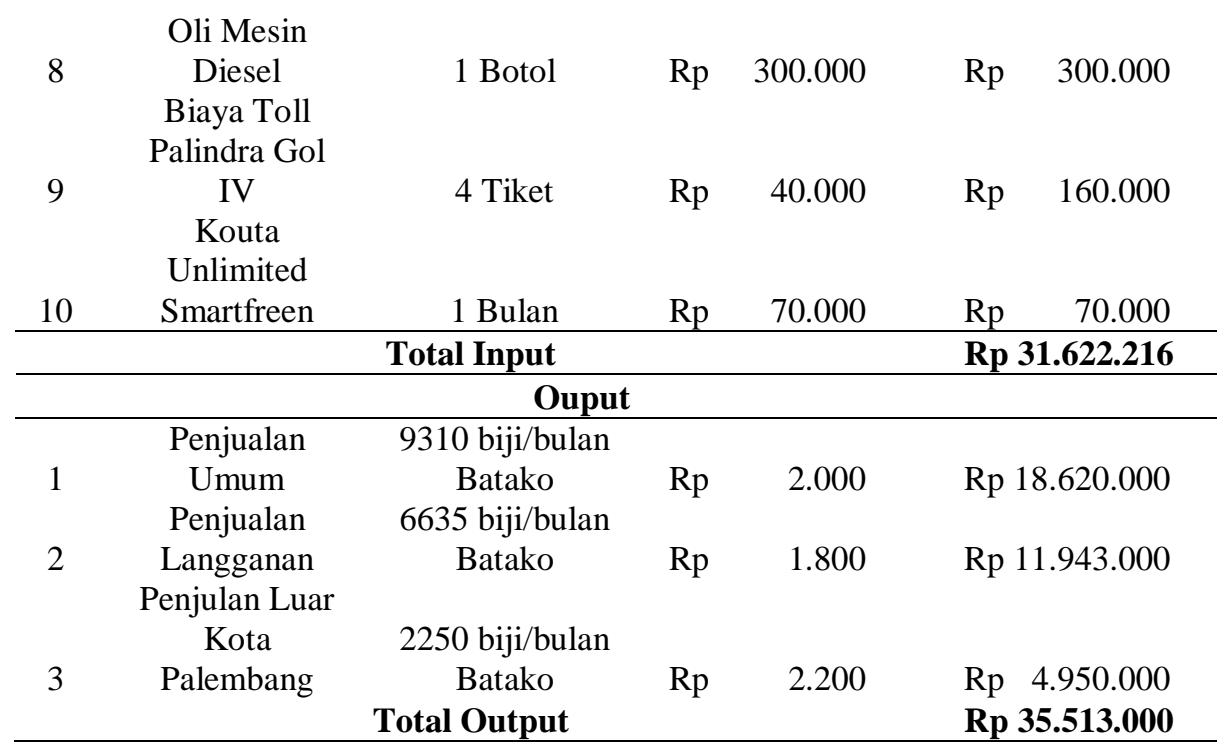

Berdasarkan tabel 3.4 jumlah input yang dikeluarkan yaitu sebesar Rp 31.622.216, sedangkan jumlah output yang dihasilkan yaitu sebesar Rp 35.513.000. Pengukuran aktivitas produktivitas sesudah implementasi dinyatakan sebagai berikut

Labour Productivity

$$
\begin{aligned}
& =\frac{\text { Total Output }}{\text { Labour Input }(\text { Biaya Pekerja })} \\
& =3.794123932 \approx 3.794
\end{aligned}
$$

Capital Productivity

$$
\begin{aligned}
& =\frac{\text { Total Output }}{\text { Capital Input }(\text { Total Input })} \\
& =1.123039574 \approx 1.123
\end{aligned}
$$

Material Productivity

$$
\begin{aligned}
& =\frac{\text { Total Output }}{\text { Material Input }(\text { Air }+ \text { Pasir }+ \text { Semen })} \\
& =1.706043428 \approx 1.706
\end{aligned}
$$

Energy Productivity

$$
\begin{aligned}
& =\frac{\text { Total Output }}{\text { Energy Input(Solar Produksi }+ \text { Solar Transportasi }+ \text { Oli Mesin }} \\
& =44.41623413 \approx 44.416
\end{aligned}
$$

Other misc.expenses

$=\frac{\text { Total Output }}{\text { Other misc.exp }(\text { Biaya Tol Gol IV }+ \text { Kouta Unlimited })}$
$=154.4043478 \approx 154.404$

48 | Strategi Penjualan Batako Ukm Areta Agung Dengan Marketing Mix Dan Produktivitas Parsial 


$$
\begin{aligned}
\text { Total Productivity } & =\frac{\text { Total Output }}{\text { Total Input }} \\
& =\frac{\text { Total Output }}{(\text { Human+Material+Capital+Energy+Other misc.exp })} \\
& =0.5652437172 \approx 0.565
\end{aligned}
$$

Berdasarkan perhitungan sebelum dan sesudah implementasi, dapat dikatakan kenaikan penjualan setelah melakukan perbaikan dalam penjualan batako pada UKM Areta Agung. Sebelum implementasi rincian produktivitas parsial yaitu Labour Productivity sebesar 3.027, Capital Productivity sebesar 0.906, Material Productivity sebesar 1.361, Energy Productivity sebesar 42.895, dan Total Productivity sebesar 0.456. sedangkan, untuk sesudah implementasi rincian produktivitas parsial yaitu Labour Productivity sebesar 3.794, Capital Productivity sebesar 1.123, Material Productivity sebesar 1.706, Energy Productivity sebesar 44.416, Other misc.expenses sebesar 154.404 dan Total Productivity sebesar 0.565.

\section{KESIMPULAN}

Berdasarkan penelitian strategi penjualan batako UKM Areta Agung dengan Marketing Mix dan Produktivitas Parsial dapat disimpulkan sebagai berikut

1) Berdasarkan hasil penentuan tingkat market share UKM Areta Agung hanya mampu menguasai pangsa pasar sebanyak $24 \%$.

2) Berdasarkan hasil analisa faktor internal dan faktor eksternal UKM Areta Agung dengan menggunakan matriks SWOT, di peroleh empat buat strategi. Strategi pertama yaitu strategi S-O yang terdiri dari Penetrasi pasar. Startegi kedua yaitu strategi W-O yang terdiri dari Menambah jam layanan pesanan, Menambah variasi harga, Meningkatkan media promosi produk. Startegi ketiga yaitu strategi S-T dengan melakukan perbaikan penjualan produk menggunakan Marketing Mix. Strategi W-T yang dilakukan yaitu Menambah saluran penjualan.

3) Dengan melakukan pendekatan Marketing Mix 4P yaitu product (produk), price (harga), promotion (promosi), place (tempat). Dari implementasi 4P akan dilakukan perbaikan yaitu Untuk yang pertama, Product (produk) yaitu menerima layanan diluar jam operasional dengan bantuan media sosial. Kedua, price (harga) yaitu menambah variasi harga menjadi umum, langganan, luar kota Palembang. Ketiga, promotion (promosi) yaitu membuat iklan penjualan online, promosi penjualan produk, publisitas, penjualan pribadi. Keempat, place (tempat) yaitu penambahan langganan depot bangunan, pemberian syarat minimal pemesanan batako untuk diluar kota Palembang.

4) Untuk produktivitas parsial penjualan sebelum implementasi didapatkan total produtivitas sebesar 0.456 dan setelah implementasi produktivitas total penjualan didapatkan sebesar 0.565 . 
(Civil Engineeering, Elektrical Engineeering and Industrial Engineeering)

Vol 18. , No : 2 Oktober 2021, p-ISSN:1907-5243, e-ISSN: 2655-8416

\section{DAFTAR PUSTAKA}

[1] Sembiring, "Buku Ajar Neonatus, Bayi, Balita, Anak Pra Sekolah", Yogyakarta: Deepublish, 2017.

[2] Tjiptono, Fandy, "Pemasaran Jasa -Prinsip, Penerapan, dan Penelitian", Andi Offset, Yogyakarta, 2014.

[3] Basu Swastha, Manajemen Pemasaran, Edisi Kedua, Cetakan Kedelapan. Jakarta: Penerbit Liberty, 2002.

[4] Galavan,R., “Doing Business Strategy”, Ireland: NuBooks, 2014.

[5] Blocher, E.J. Et. Al, "Cost Manajemen", Manajemen Biaya Penekanan Strategis. Jakarta : Salemba Empat, 2007.

[6] Telsang, Martand, Industrial Engineering and Production Management. Ram Nagar, New Delhi-110055, 2008. 